\title{
The Influence of Family Characteristics, Family Financial Management, and Saving Intensity on The Size of Farmer Families' Saving at Ciaruteun Ilir Villages
}

\author{
Susanti Kartikasari \\ Graduate School of Management Business, \\ Bogor Agricultural University
}

\author{
Istiqlaliyah Muflikhati* \\ Department of Family and Consumer Sciences, \\ Faculty of Human Ecology, \\ Bogor Agricultural University
}

*Corresponding author: istiqlaliyah@yahoo.com

\begin{abstract}
The aim of this study was to analyze the influence of financial management on saving behavior in farmer families. This research uses cross-sectional design conducted in Ciaruteun Ilir Village with purposive selection location. The study was performed in 70 randomly selected families with working wife. The results showed that financial management of farmer family is poor. A total of 71.4 percent of farmer families has saving. The results of multiple linear regression showed that the bigger the family size, the weaker the financial management. Nonetheless, the number of assets and higher family income would increase financial management. Logistic regression showed that family with better financial management is more likely to have better saving. Family size would reduce saving, while family income would increase saving.
\end{abstract}

Keywords: farmer families, financial management, saving behavior

\begin{abstract}
Abstrak. Tujuan penelitian ini adalah menganalisis pengaruh manajemen keuangan terhadap perilaku menabung pada keluarga petani. Penelitian ini menggunakan desain cross sectional study yang dilakukan di Desa Ciaruteun Ilir dengan pemilihan lokasi secara purposive. Contoh dalam penelitian ini adalah keluarga petani dengan istri bekerja sebanyak 70 keluarga yang diambil secara acak. Hasil penelitian menunjukkan bahwa manajemen keuangan keluarga petani tergolong kurang baik. Sebanyak 71.4 persen keluarga petani melakukan kegiatan menabung, namun tidak semuanya rutin menabung. Hasil uji regresi linear berganda menunjukkan bahwa semakin besar keluarga akan menurunkan manajemen keuangan keluarga, tetapi semakin banyak jumlah jenis aset dan semakin tinggi pendapatan keluarga akan meningkatkan manajemen keuangan keluarga. Hasil uji regresi logistik menunjukkan bahwa keluarga dengan manajemen keuangan lebih baik berpeluang lebih besar untuk menabung dan lebih sering untuk menabung. Selanjutnya, semakin besar keluarga akan menurunkan besar tabungan keluarga dan semakin tinggi pendapatan keluarga akan meningkatkan besar tabungan keluarga.
\end{abstract}

Kata kunci: keluarga petani, manajemen keuangan, perilaku menabung 


\section{Introduction}

Financial issue is a crucial issue in the life of a person or family. In general, farm families have low-income and classified as poor family (Firdaus and Sunarti, 2009). Risda (2010) showed that incomes in the agricultural sector have not been sufficient to finance the household. Economic resilience can be realized if the main organizer is able to arrange properly all the aspects related to the needs of families, particularly in managing family finances in order to fullfill the basic needs of each family member (Sambiran, 2006). Suandi (2010) stated that financial management in a family is very important in promoting the economic welfare of the family in the allocation for consumption, investment purposes, and business development.

Abdurachman, Mulyani, and Nurida (2009) states that the low and uncertain income earned by family farmers will indirectly cause problems in his family, not to mention if farmers have puso or failed harvests, the problems faced by farmers will increase. It should be able to make family farmers prepare for the future needs now and in the future. One way that can be done is to have financial management and saving habits so that families are not only allocates revenue for current consumption, but also have savings or savings for future needs (Yao et al., 2011).

The importance of money in human life, especially the family is not only related to the amount of money you have, but also the earned money to spend for the welfare of the family. According to Kusumo and Simanjuntak (2009), if the family is good at organizing earnings, it will rise the family satisfaction. Firdaus and Sunarti (2009) stated that the better management of family finances the welfare of the family, the better families who apply good financial management which must be able to allocate revenue in accordance with the needs of the family. Meanwhile, income families who do not apply good financial management will run away or even less (Rahmayani and Hartayo 2009).

Low and uncertain income will indirectly affect the family's financial situation. Economic stability within the family is one of the factors that will determine the happiness in the family because the income is not sufficient for the family that is the main cause of contention in the family (Rodhiyah 2012). The high cost of living today which tends to increase from year to year, the economic situation that is not always good and that is not always healthy physical further add problems to be faced by the family. Under these conditions, the family had to find a way out and prepare for the needs of tomorrow, one way is through the financial management whose revenues are not discharged simply and can be used when needed.

Financial management activities in the family can be done by making regular financial planning, executing what already exists in the planning, and evaluating expenditures to discuss financial problems in the family, and save for the future (Ika, 2011). Savings play an important role in the lives of individuals and communities. According to Lewis et al. (1995), saving is an activity designated to the resource saving on a regular basis in order to achieve a goal. Bryant and Zick (2006) states that the resources at present used for saving will produce satisfaction in the future. According Hoos (2010), there are several 
options available for families to save that formal financial institutions and nonformal.

The motivation to save in a family could be very diverse. According to Keynes (1939) There are some various saving motivation in a family, i.e. guard motif, life cycle motif (future or retirement), improving living standards motif, bequest motif, and motif of capital rise to start a business. While according to Bryant and Zick (2006), motivation of saving is to protect uncertainty (unemployement and health), to purchace cheap goods, heritage, and to be on alert due to the uncertainty of income.

While the motivation to save by Bryant and Zick (2006) is to protect the uncertainty (unemployment and health), the current consumption of cheap goods, heritage, and guard because of revenue uncertainties.

Based on the above information, this study aims to describe the influence of factors including the financial management of the savings behavior in the family farmer. The specific objectives of this study, namely: (1) identifying the family financial management, savings behavior and characteristics of farming families; (2) analyzing the relationship between family financial management and saving behavior; (3) analyzing the effect of family characteristics on the financial management; (4) analyzing the influence of family financial management of the saving behavior; and (5) analyzing the influence of family financial management and saving up to big savings intensity.

\section{Review Literature}

One of the functions that must be fullfilled by the family is the economic function by fulfilling all the needs of family members. Limitations of revenue require good financial management in order to be used as optimally as possible to fullfill the needs of the family. According Yohnson (2004), one of the causes of the problems in the family is due to the inability of families in managing family finances. Families with a good ability to understand and manage family resources will be able to utilize family resources, especially financial or family income to ensure their ability to optimally fullfill the family needs and income is not exhausted granted.

The saving activity is one way to do financial management by the family to fullfill the needs of the family and is one of the activities of financial management which is very important to consider their productive and non productive period in a person's life. In other words, saving money is one way to fullfill the needs of family life when it is not productive or during the critical period. This is similar with Keynes (1939) in Hoos (2010) that states one of the motivations to save the family is the motive of the life cycle that is for the future or retirement when it does not generate revenue. Families can take advantage of financial resources or income families, especially families with up will be assured for future needs, families are able to fullfill the needs of the family and be able to overcome the financial problems that faced. 


\section{Participant}

\section{Method}

This study was a cross sectional study and the collection of data is done with an interview using a questionnaire. This research was conducted in the village of Ciaruteun Ilir, District Cibungbulang, Bogor in which the location was selected purposively with consideration that most people in the village live as farmers. The study population is peasant family consisting of a husband and wife who worked in the village Ciaruteun Ilir. Respondents in this study were working wives of family farmers, 70 people. They came from two Ciaruteun Ilir Kampung Jaya and Kampung Wangun that were selected by simple random sampling technique.

\section{Measurement}

The research data were from primary and secondary data. The primary data were obtained from direct interviews covering data of family characteristics (age, education, occupation, family size, income, expenses, assets and ownership types), family financial management, and savings behavior. The secondary data in the study include the population of the village Ciaruteun Ilir. The saving behavior was seen from the activities of saving (saving or not saving), the saving and the intensity of saving (routine and non-routine).

Financial management was measured from planning (16 statement), execution (statement 16), and monitoring and evaluation (5 statements). Each grain of revelation provided four answers scale $(1=$ never, $2=$ sometimes, $3=$ often, $4=$ always). Furthermore, each sub-item score was transformed into the form of an index before all the sub-item scores were summed and divided according to sub-item. Then the total scores achieved grade were inserted into intervals. Interval class was divided into three categories: poor $(<50.0)$, good enough (50.0-75.0), and either (> 75.0).

$$
\text { Interval kelas }(I)=\frac{\text { skor maksimum }(N T)-\text { skor minimum }(N R)}{\text { jumlah kelas }}
$$

The division of categories refers to the following formula:

Less good: (NR) to $(\mathrm{NR}+\mathrm{I})$

Pretty good $(\mathrm{NR}+\mathrm{I})+1$ to $(\mathrm{NR}+2 \mathrm{I})$

Good: $(\mathrm{NR}+2 \mathrm{I})+1$ to $(\mathrm{NT})$

\section{Analysis}

The collected data was processed using descriptive and inference analysis. Descriptive analysis includes averaging, standard deviation, minimum, and maximum used to describe the characteristics of the family. Meanwhile, analysis of inference included Chi-Square test to look at the relationship between financial management and savings behavior family, logistic regression was used to analyze the factors that influenced saving behavior, and multiple linear regression tests were used to analyze the factors that affected financial management family. 


\section{Result}

\section{Family Characteristic}

Large families were measured by the number of family members. BKKBN (1995) divided the families into three groups based on the number of family members, the family of small ( $\leq 4$ people), middle family (5-7 people), and a large family $(>7)$. More than half of family farmers were small family category $(57.1 \%)$, most of his family including moderate $(38.6 \%)$, and the rest was a big family $(4.3 \%)$. Thus, the average farming family consisted of 4 people $(\mathrm{SD}=1.4)$. Husband on farm families average age was 45 years $(\mathrm{SD}=13.8)$, while the wife was in the average age of 38 years $(\mathrm{SD}=11.9)$. Last education of husband $(44.3 \%)$ and wife (42.9\%) in the family farmer was not completed - primary school/equivalent with an average length of four years of education.

In terms of expenses including food and non-food, farm families in this study were at an interval of Rp317.000 - Rp3.067.583 with average Rp1.194.623. High number of family spending does not necessarily indicate that income is also high because it depends on the number of members or dependents. Size that could reflect the condition of the expenditure for the entire family is expense per capita known to reach an average of Rp277.615 per month.

Husband's work status is divided into peasant proprietors $(47.1 \%)$, smallholder farmers (40\%), and agricultural laborers (12.9\%). Although the work is the responsibility of the head of the family, but the wife in a family of farmers also work to supplement the family income, among others, as traders (5.7\%), teachers $(2.8 \%)$, agricultural laborers $(88.7 \%)$, and the mortgagee $(2.8 \%)$. However, the husband remains the largest contribution to the family income (79\%). Large income ranged between Rp300,000 note-Rp4.100.000 with an average family income of Rp1.833.115 per month and the average income per capita amounted to Rp338.825 per month.

To determine the financial condition of the family farmers, families are classified into three conditions, namely financial surplus, break even, and the deficit. The financial condition of surplus occurs when the family income is higher than expenditure; therefore, family finances are in a safe position. The condition occurs when the break even amount of income is equal to expenses or balance - equal to zero. The condition occurs when the deficit is lower than the revenue expenditure that requires improvement efforts, such as by adding revenue, sales of assets, savings, or asking help. Overall, more than half of farm families $(52.9 \%)$ are in surplus or favorable financial condition and the rest is in a deficit financial condition.

Ownership of farm family assets was identified through the ownership of a valuable economic resource material, including home ownership, transportation, livestock, electronic equipment, household appliances, furniture, agricultural lands, and other valuables. More than three-quarters of farm families have already owned their own homes $(81.4 \%)$ while the rest $(18.6 \%)$ lives with his parents. Transport equipment, the most widely owned by farm families, is motorcycles $(40.0 \%)$, only a small proportion $(1.4 \%)$ that has a pickup truck that is generally used to transport the vegetables which are ready to be marketed. Owners of livestock asset owned by family farmers are the chicken for the maintenance and 
utilization which is relatively easy (28.6\%). Other assets, the most widely held, is television as an asset tool electronic (95.7\%), gas stove as household assets $(84.3 \%)$, the bed as an asset of furniture $(91.4 \%)$, and the field $(47.1 \%)$, and other valuables in the form of gold $(15.7 \%)$. Thus, more than half of farm families have a number of asset types 10-20 types.

\section{Family Financial Management}

Management starts from planning and then implementation of the use of the existing resources to achieve the desired goal (Deacon and Firebaugh, 1988). According Puspitawati (2012), there are three stages in family financial management, including planning, implementation, monitoring and evaluation.

Planning is the first concrete step taken, which is then used as the basis of management execution (Siagian, 2005). Farm family financial management planning was classified as less good (score 38.5). Planning form that most often committed by family farmers is always a discussion with the family members of both the husband and children in family financial planning (58.6\%). Unexpected budget is important for farm families to face financial problems that suddenly occur, such as crop failure, sick of family members, or other things that are abrupt. However, only a small portion of farmer families has the budget (4.3\%).

According to Deacon and Firebaugh (1988) implementation of an action based on plans has been made previously. In practice, the average farm family financial management is not good (score 35.4). More than half of farm families $(51.4 \%)$ never deposit money or the residual income is unpredictable and there are farm families $(21.7 \%)$ who always have difficulty in managing finances. Recording the expenditure will help to understand what has been done against the money they have and help control expenses and the family finances, but almost all farm families (95.7\%) have never been recorded any expenses or use the money they have.

Gross et al (1963) stated that the evaluation of the use of money is no less important than planning and execution since in this stage, it does not only decide the success of the planning and implementation but also measure the satisfaction that is felt to achieve the goal. The average score of the monitoring and evaluation of the financial management of farming families is 34.1. Overall farm families are always discussions to solve financial problems with a good family with a husband and children (37.1\%). More than three-quarters of farm families (78.6\%) never change the budget planning that is not appropriate.

Table 1 The distribution of farm families by categories of family financial management

\begin{tabular}{lcccc}
\hline $\begin{array}{l}\text { Family Financial } \\
\text { Management }\end{array}$ & $\begin{array}{c}\text { Less good } \\
(<50.00)\end{array}$ & $\begin{array}{c}\text { Quite Good } \\
(50.00-75.00)\end{array}$ & $\begin{array}{c}\text { Good } \\
(>75.00)\end{array}$ & $\begin{array}{c}\text { Average } \\
\text { Index }\end{array}$ \\
\hline Planning & 67.1 & 32.9 & 0.0 & 38.5 \\
Implementation & 87.1 & 12.9 & 0.0 & 35.4 \\
$\begin{array}{l}\text { Monitoring and Evaluation } \\
\text { Total of financial }\end{array}$ & 92.9 & 7.1 & 0.0 & 34.1 \\
management & 84.3 & 15.7 & 0.0 & 36.0 \\
\hline
\end{tabular}




\section{Saving Behavior}

Based on the identification of every aspect of financial management, more than three-quarters of farm families included in the unfavorable category $(84.3 \%)$ and the rest belongs to the category quite well. The distribution of the family based on family financial management is presented in Table 1.

Overall farm families in this study have done saving activities (71.4\%), good farming family owners and non-owners. Meanwhile, the highest proportion of families of farmers who did not save are non-owners farming families (35.1\%). Most families are not saving the earned money assuming that every harvest is not enough if it is set aside for savings.

Most farming households save money on non-formal financial institutions, with the highest proportion, that are gathering and school children (each 48\%). Saving money through gathering activities are found to be troublesome because it is usually money social gathering taken to the house of the social gathering while saving money in the child's school seems not troublesome due to its small nominal. There are also several families of farmers who save in the form of money, and have savings in the form of gold with an average of 20 grams per family $(15.7 \%)$.

More than three-quarters of farm families $(88.0 \%)$ regularly save money by saving the most frequency to do every day (48\%), generally saving money in their child's school. Meanwhile, family farmers who save each week $(28 \%)$ generally save money in Baitul Maal and family farmers who save every month (40\%) generally save money in a social gathering.

Family farmers who save every day on average set aside money amounting to Rp7.654. On the farm families who save every week, the average saving is Rp46.909 while family farmers who save each month can save at Rp175.857 per month. In addition, there is also a family of farmers who save every harvest season with an average of 100,000 per harvest. Thus, the savings is greater in general farm families on a monthly basis to reach an average Rp137.214.

Family farmers stated that motive or purpose of saving is various. The most preferred destination is to anticipate unpredictable events (64\%). It is understandable in the agricultural business events, such as crop failures and natural disasters which are difficult to predict. Without anticipating it, there will be problems for the survival of family farmers. In addition to anticipate unexpected events, some farm families also stated other purposes, namely as saving the old days (8\%), children's education (54\%), to purchase assets $(2 \%)$, as a legacy $(8 \%)$, to starting a new business $(4 \%)$, recreation fees $(6 \%)$, the purpose of the next planting season $(30 \%)$, and the cost of child marriage (2\%).

\section{Financial Management Relations friendly Saving Behaviour}

Chi-Square test results show that there is a relationship between the financial management with the activities undertaken to save the family farmer ( $\mathrm{p}$ $=0.022$ ). Family farmers who do not perform saving activities are known to be the family who tend to have poor financial management. Instead, most families are doing the activities of saving a family with pretty good financial management. 
Table 2 Relationship of family financial management with saving behavior

\begin{tabular}{lcccccc}
\hline Financial Management & \multicolumn{2}{c}{ No Saving } & \multicolumn{2}{c}{ Saving } & \multicolumn{2}{c}{ Total } \\
\cline { 2 - 7 } & $\mathrm{N}$ & $\%$ & $\mathrm{~N}$ & $\%$ & $\mathrm{~N}$ & $\%$ \\
\hline Less well & 13 & 65.0 & 15 & 30.0 & 28 & 40.0 \\
Quite good & 7 & 35.0 & 35 & 70.0 & 42 & 60.0 \\
Total & 20 & 100.0 & 50 & 100.0 & 70 & 100.0 \\
\hline
\end{tabular}

\section{Characteristics of the influence of the Family Financial Management}

The results of multiple linear regression tests on the effect of family characteristics on the financial management of farm families are shown in Table 3 . The results show that family sizes have significant negative effect on the financial management of the family $(\beta=-2167, p=0.006)$. It means that the increase of family members would reduce the ability in managing family finances. On the other hand, the number of types of asset significant give positive effect on the financial management of the family $(\beta=0581, p=0.031)$, in which families with more diverse types of assets will show the better financial management. The same thing happens in families with a high family income. Family income also leaves a significant positive effect on family financial management.

Meanwhile, the husband's work known does not give a significant effect to the financial management of the family. In this research model, husband's work is categorized into two categories, that is, owner farmers and non-owner farmers.

Table 3 Regression test results influence the characteristics of the family against family financial management

\begin{tabular}{lccc}
\hline \multirow{2}{*}{ Variable } & \multicolumn{3}{c}{ Family Management } \\
\cline { 2 - 4 } & Unstandardized $\beta$ & Standardized $\beta$ & Sig. \\
\hline Konstanta & 26.411 & - & 0.002 \\
Wife age (year) & -0.187 & -0.043 & 0.142 \\
Wife education (year) & 0.573 & 0.389 & 0.380 \\
Husband work (0=non owner, 1=owner) & 0.449 & 0.307 & 0.896 \\
Family size (people) & -2.167 & -0.509 & $0.006^{* *}$ \\
Asset number (type) & 0.581 & 0.401 & $0.031^{*}$ \\
Family income (Rp/month) & 2.546 & 0.491 & $0.030^{*}$ \\
\hline F & & 6.001 & \\
R & & 0.603 & \\
Adjusted $R$ Square & \multicolumn{3}{c}{0.303} \\
Sig. & \multicolumn{3}{c}{$0.000 \mathrm{a}$} \\
\hline Note.
\end{tabular}

Note. $(*)$ Significant at $\mathrm{P}<0.05 ;(* *)$ Significant at $\mathrm{p}<0: 01$

\section{Influence of Family Characteristics and Financial Management to Conduct Family Savings}

Family characteristics and financial management influencing savings behavior were analyzed using logistic regression analysis. The results of the analysis in Table 4 shows that this model can account for 50.5 percent of the factors that influence the activities of saving while the rest (49.5\%) is explained by other variables not examined. Meanwhile, the value of Nagelkerke on the saving intensity is 0.548 . It indicates that the model explains 54.8 percent of the influence of factors on the intensity of saving and the rest (45.2\%) is explained by 
other variables not examined. Results showed that families with better financial management had 1.3 times greater odds of saving and routine in doing so.

Table 4 Logistic regression coefficient factors influencing savings behavior

\begin{tabular}{|c|c|c|c|c|c|c|}
\hline \multirow[t]{2}{*}{ Variable } & \multicolumn{3}{|c|}{$\begin{array}{l}\text { Saving Activity } \\
(0=\text { no, } 1=\text { yes })\end{array}$} & \multicolumn{3}{|c|}{$\begin{array}{c}\text { Saving Intensity } \\
(0=\text { no routine }, 1=\text { routine })\end{array}$} \\
\hline & $\mathrm{B}$ & $\operatorname{Exp}(\mathrm{B})$ & .Sig & $\mathrm{B}$ & $\operatorname{Exp}(\mathrm{B})$ & .Sig \\
\hline Konstanta & -11.454 & 0.000 & 0.016 & -12.700 & 0.000 & 0.007 \\
\hline Wife age (year) & -0.011 & 0.989 & 0.778 & -0.005 & 1.005 & 0.904 \\
\hline Wife education (year) & 0.187 & 0.830 & 0.362 & 0.408 & 0.953 & 0.808 \\
\hline $\begin{array}{l}\text { Husband work }(0=\text { non } \\
\text { owner, } 1=\text { owner })\end{array}$ & 1.354 & 0.261 & 0.158 & 0.386 & 0.680 & 0.661 \\
\hline Family size (people) & 0.575 & 1.778 & 0.101 & 0.503 & 1.654 & 0.154 \\
\hline Asset number (type) & 0.182 & 1.200 & 0.082 & 0.133 & 1.143 & 0.151 \\
\hline $\begin{array}{l}\text { Family income } \\
\text { (Rp/month) }\end{array}$ & 0.000 & 1.000 & 0.991 & 0.000 & 1.000 & 0.891 \\
\hline $\begin{array}{l}\text { Family management } \\
\text { (score) }\end{array}$ & 0.275 & 1.316 & $0.003 * *$ & 0.275 & 1.317 & $0.002 * *$ \\
\hline Nagelkerke $R^{2}$ & & 0.505 & & & 0.548 & \\
\hline
\end{tabular}

Note. (*) Significant at P $<0.05$; (**) Significant at $\mathrm{p}<0: 01$

\section{Characteristics Influence Family, Family Financial Management, and the intensity of Saving the Big Savings}

Meanwhile, the number of savings analysis at farmer families in this study is shown in Tables 5 through multiple linear regression tests. The test results showed that a large family has a greatly significant negative effect on savings, which means increasing the number of family members, would reduce the savings of farm families. In contrast, family income has a significantly positive effect on household savings which indicate that families with high incomes will be more likely to save in large numbers anyway. The model explained 21.5 percent of the influence of the factors tested against large household savings.

Table 5 Coefficient of linear regression the factors that affect a large peasant family savings

\begin{tabular}{lccc}
\hline & \multicolumn{3}{c}{ Saving Amount } \\
\cline { 2 - 4 } Variable & Unstandardized & Standardized & Sig. \\
\hline Konstanta & B & B & 0.004 \\
Wife age (year) & 20.413 & - & 0.236 \\
Wife education (year) & 0.188 & 0.132 & 0.415 \\
Husband work (0=non owner, 1=owner) & 0.089 & 0.083 & 0.107 \\
Family size (people) & 0.287 & 0.186 & $0.041^{*}$ \\
Asset number (type) & -2.154 & -0.458 & 0.052 \\
Family income (Rp/month) & 0.298 & 0.178 & $0.017^{*}$ \\
Family management (score) & 0.291 & 0.169 & 0.116 \\
Saving intenstity (0=no routine, 1= & 0.213 & 0.158 & 0.242 \\
routine) & 0.195 & 0.141 & \\
\hline F & & & \\
R & & 4.153 & 0.532 \\
Adjusted R square & & 0.215 & \\
Sig. & & $0.000 \mathrm{a}$ & \\
\hline
\end{tabular}




\section{Discussion}

Financial management is done to allocate the financial needs and the ability of the family. Guhardja et al. (1992) states that financial management can not create resources that are not sufficient to fullfill the needs and desires, but management can help establish the use of limited resources to be optimal in their utilization. Financial management of the family consists of three phases, including planning, implementation, monitoring and evaluation (Puspitawati, 2012). Planning is the process of planning a financial objectives (financial desires that wanted to be realized) for short-term goals, medium term and long term (Senduk, 2001). According Siswono (2005), the implementation of the financial management is a process and a series of activities to try to get a job can be carried out in accordance with the predetermined plan and steps that must be passed. Meanwhile, according to the monitoring and evaluation stages, to compare plans have been made to the achievement of its realization. Gross et al (1963) stated that in the phase of monitoring and evaluation does not only decide the success of the planning and implementation but also measure the satisfaction that is felt to achieve the goal. The results showed that all three phases of financial management in the study were classified as less good.

Based on the regression test results, familiy size has significantly negative effect on family financial management. This suggests that the greater number of family members, the lower the family's ability to manage finances. This is in similar with research conducted by Fajrin (2011) which states that familiy size has significantly negative effect on management of family finance. Meanwhile, asset type and number of family income have significantly positive effect on family financial management. This shows that the higher the number of types of assets and income of the family, the better the management of family finances. This is in line with research conducted by Kiyosaki (2003) in Sambiran (2006) which states that one of the factors that affect financial management is an asset that belongs to the family. Alabi, Ogbimi, and Soyebo (2006) stated that income is the primary resource families which will be used to purchase a variety of family needs. The more family can manage income possesed, the better the family's financial manager who will get the best results or output.

Chi-Square test results show that there is a relationship between the financial management and the activities undertaken to save at the family farmer. Most of family farmers who perform the activities of saving are who have a fairly good financial management. This shows that the importance of family financial management is to allocate income optimally. In other words, a family financial management can produce savings that can be used when the family was needed.

Saving is an activity in which the resource is done in present to produce satisfaction in the future (Bryant and Zick, 2006). According to Kibet et al. (2009), one of the main factors in determining the choice of the institution in which the agency can save money is accepted by the community and the surrounding environment. Families have several options for saving formal institutions (banks, PNPM, Baitul Maal, and cooperatives) and non-formal institutions (saving at home, gathering, or saving in a group). In thi study, the 
place to save the most widely available is in the neighborhood where the family farmer is gathering, mobile banks, and Baitul Maal.

Overall family farmers do saving activities but not all do it regularly. Regular saving family is generally a family who saves in their children's school, gathering, and Baitul Maal. Based on the analysis, the economic factor is not the only factor that makes family farmers not do the activities of saving. More than half the families of farmers who do not carry out the activities of saving have the surplus financial condition or the earnings are greater than the expenditure incurred by the family farmer. Family farmers who do not save on average feel that the income is considered too mediocre to fullfill their daily needs and not enough if it should save. Meanwhile, according to Hoos (2010), not all poor households are too poor to save. Furthermore, he thought that inability of households to save can be categorized into households that can not manage their finance. In fact, they poor households must manage their finance because of their variety of income and uncertain income .

Family farmers save an average 10.2 percent of total revenue. This result is lower than the results of research by Brata (1999) which states that the average total family income that is saved sample by 37 percent. While the research results by Rochaeni (2005) showed that the average family income saved farmer amounted to 26.7 percent. On the whole, family farmer in this study did not save the banking institutions. This is according to research conducted by Sutarno (2005) and Kusumo and Simanjuntak (2009) which states that families in rural areas do not save savings activities in banking institutions, but in the non-formal financial institutions.

Place to save the most widely selected bu farmers is social gatherong money with a reason not to difficult because usually social gathering money is taken home. This is understandable because almost all the wives of farmer families have a higher activity each day. Thus, choosing a place to save is easy to reach the best option for them, In addition, the surrounding neighborhood families also actively encourage farmers to stay farming families following the gathering. These results are consistent with research conducted by Sofiarrahmi (2012) which states that the gathering into place to save is the most preferred by the family example. The other saving places selected by family farmers are school children on the grounds while children school and it does not seem to spend every day because usually the amount of money owned by a family of farmers who save in their child's school is not to big.

This is understandable because almost all the wives of farmer families have a higher activity each day. Thus, choosing a place to save is easy to reach the best option for them, In addition, the surrounding neighborhood families also actively encourage farmers to stay farming families following the gathering. These results are consistent with research conducted by Sofiarrahmi (2012) which states that the gathering into place to save is the most preferred by the family example. The other saving places selected by family farmers are school children on the grounds while children school and it does not seem to spend every day because usually the amount of money owned by a family of farmers who save in their child's school is not too big. 
Motivation to saving in the family farmer diversified. The results showed that the proportion of motivation to save at most of the family farmer is the precaution motive that is the motive to anticipate unpredictable events, such as natural disasters and crop failures. This is according to research conducted by Yao et al. (2011) which states that one of the motivations to save is to prepare for emergencies in the future. Also in line with research conducted Hoos (2010), which showed that most of the reasons of poor families to save is to motive precaution. Therefore, savings which are suitable for poor families is savings that easily retrieved at any time for use during an emergency interest.

The results showed that the management of family finances gives significantly positive effect on saving activities and intensity. Families who have a better family financial management have a 1.3 times greater chance to perform activities of savings and routinity savings, which mean families with good financial management tend to perform routine activities of saving and more saving. The results showed that the addition of family size will bring down of household savings. This is in line with research conducted by Fisher and Anong (2012). Meanwhile, the addition of family income would increase family savings anyway. This is in line with research conducted by Rehman, Faridi, and Bashir (2010).

\section{Conclusion}

\section{Conclusion and Suggestion}

The overall financial management of farm families is classified as poor. The variables that affect the family's financial management are a family size, the number of types of assets, and family income. The greater the number of family members, the lower the management of family finance dan more number of types of assets, and the higher the family income that would improve the management of family finances. The results showed that the average farmer families save in school children and social gathering money with the main objective to anticipate events that are unpredictable.

More than half of family farmers belong to small family category. Nearly half the age of the husband belongs to middle age category, while more than half of the wife belongs to the category of young adults. The highest education level of most family farmers is not completed - primary school/ equivalent, even they whose status is still active never go to school.

Family financial management gives positive effect on savings behavior. Families with better financial management tend to have a better chance to perform the activities of saving and more routine to save. The results also show that the greater the number of family members drop large of family savings, the higher the family income would be - a big boost for household savings. Meanwhile, financial management is significantly positive which is associated with the activities of saving, which means that a family with pretty good financial management tends to perform the activities of saving. This shows the importance of financial management so that families do savings that can be used when needed. 


\section{Suggestion}

Based on the results of research, the financial management of farming families in the study site was classified as less good, therefore, it is important to do a counseling and training program relating to a financial management so that families are able to perform well because there are many families that do not do the saving even though their financial condition is surplus. . In addition, there are many families with deficit financial condition, including poor families. Counseling is also geared to explain to the family especially his wife as a financial controller in the family that the activities of saving are not only done when there is residual income, but they need to deliberately set aside as other basic needs. Regarding future studies, researchers could add other variables, such as lifestyle and perception.

\section{Reference}

Abdurachman, A., Mulyani, A., \& Nurida, N. L. (2009). Conditions anticipation of the limitations of agricultural land on the Java Island. Journal of Agricultural Innovation Development, 2(4), 283-285.

Alabi, D. L., Ogbimi, G. E., \& Soyebo, K. O. (2006). Factors enhancing effective financial management of rural women in Osun State. Journal of Sosial Sience, 1(1), 5-10.

Brata, A. G. (1999). Household saving behavior: The case of rural industry in Bantul. CSIS, 28(1), 75-86.

Bryant, W. K., \& Zick, C. D. (2006). The Economic Organization of the Household (2nd ed.).United State of America (US): Cambridge University Press.

Deacon, R. E, \& Firebaugh, F. M. (1988). Family Resource Management: Principle and Application (2nd ed.). United State of America (US): Allyn and Bacon Inc.

Fajrin, F. (2011). Financial management and family welfare of women factory workers in Bogor [skripsi]. Diperoleh dari http://repository.ipb.ac.id/handle/123456789/53472.

Firdaus, \& Sunarti, E. (2009). The relationship between economic pressure, financial management, and coping mechanisms with family welfare women tea pickers. Journal of Family and Consumer Sciences, 2(1), 21- 31.

Fisher, P.J., Anong, S.T. Relationship of Saving Motives to Saving Habits. Journal of Financial Counseling and Planning, Volume 23, Issue 12012

Guhardja, S., Puspitawati, H., Hartoyo, Martianto, D. (1992). Family Resource Management diktat. Department of Community Nutrition and Family Resources, Faculty of Agriculture, Bogor Agricultural University.

Gross, I. H., Crandall, E. W, \& Knoll, M. M. (1963). Management for Modern Families. New York (US): Meredith Publishing Company.

Hoos, K. E. (2010). Saving behavior in Cebu City [thesis]. Utrecht, Dutch: Utrecht University. 
Ika, S. A. (2011). Personality traits as a determinant of family financial planning. Humanities Development Journal, , 11(2), 118-126.

Kashmir. (2010). Introduction to Financial Management. Jakarta, Indonesia: Kencana Indonesia.

Keynes, J. M. (1939). The General Theory of Employment, Interest and Money. London, UK: MacMillan.

Kibet, L. K., Mutai, B. K., Ouma, D. E., Ouma, S. A., \& Owuor, G. (2009). Determinants of household saving: Case study of smallholder farmers, entrepreneurs and teachers in rural areas of Kenya. Journal of Development and Agricultural Economics, 1(7), 137-143.

Kusumo, R. A. B., \& Simanjuntak, M. (2009). The level of satisfaction of lowincome families to the resources available. Journal of Family and Consumer Sciences, 2(2), 122-136.

Lewis, A., Webley, P., \& Furnham, A. (1995). The new economic mind. The social psychology of economic behaviour. Hemel Hempstead, UK: Harvester Wheatsheaf

Puspitawati, H. (2012). Gender and Family. Concept and Reality in Indonesia. Bogor, Indonesia: IPB Press.

Rahmayani, I., \& Hartoyo. (2009). Consumers Financial Management diktat. Department of Family and Consumer Sciences, Faculty of Human Ecology, Bogor Agricultural University.

Rehman, H., Faridi, M. Z., \& Bashir, F. (2010). Household saving behavior in Pakistan: A case of Multan District. Journal of Social Science, 30 (1), 17-29.

Risda, A. (2010). Analysis of family income farmers in the District of Bangkinang Seberang Binuang Kampar regency [thesis]. Padang (ID): Andalas University

Rochaeni, S. (2005). Time employment, income and household expenditure farmers in economic activity in the Village Situgede Bogor City [thesis]. Bogor (ID): Bogor Agricultural University.

Sambiran. (2006). Perception housewife in managing family finances. Executive Journal, 5 (1), 372-380.

Senduk, S. (2001). Managing the Family Financial. Jakarta, Indonesia: PT. Elex Media Komputindo.

Siagian, S. P. (2005). Managerial functions. Jakarta, Indonesia: PT. Earth Akasara.

Siswono, H. B. (2005). Introduction to Management. Jakarta, Indonesia: PT. Earth Literacy.

Sofiarrahmi, M. (2012). Analysis of Gender Roles and Saving Behavior in Families Fisherman (A Case Study in the village of Pelabuhan Ratu, Sukabumi) [thesis]. Bogor (ID): Bogor Agricultural University.

Suandi. (2010). Socio-demographic studies and resource management to the economic welfare of the family in the district of Kerinci in Jambi Province. Journal Agrisep.

Sutarno. (2005). Saving behavior of households in the villages in the district of Klaten district Delanggu [thesis]. Semarang (ID): Diponegoro University.

Yao, R., Wang, F., Weagley, R. O., \& Lao, L. (2011). Household saving motives: Comparing the American and Chinese consumers. Family and Consumers Science Research Journal, 40 (1), 28-44. 
Yohnson. (2004). The role of universities in Surabaya in increasing the number of settled families in Surabaya (Series family financial research). Journal of Management and Entrepreneurship, 6 (1), 54-71. Available on http://jurnalmanajemen.petra.ac.id/index.php/man/article/view/15649/15641. 